Provided for non-commercial research and education use. Not for reproduction, distribution or commercial use.

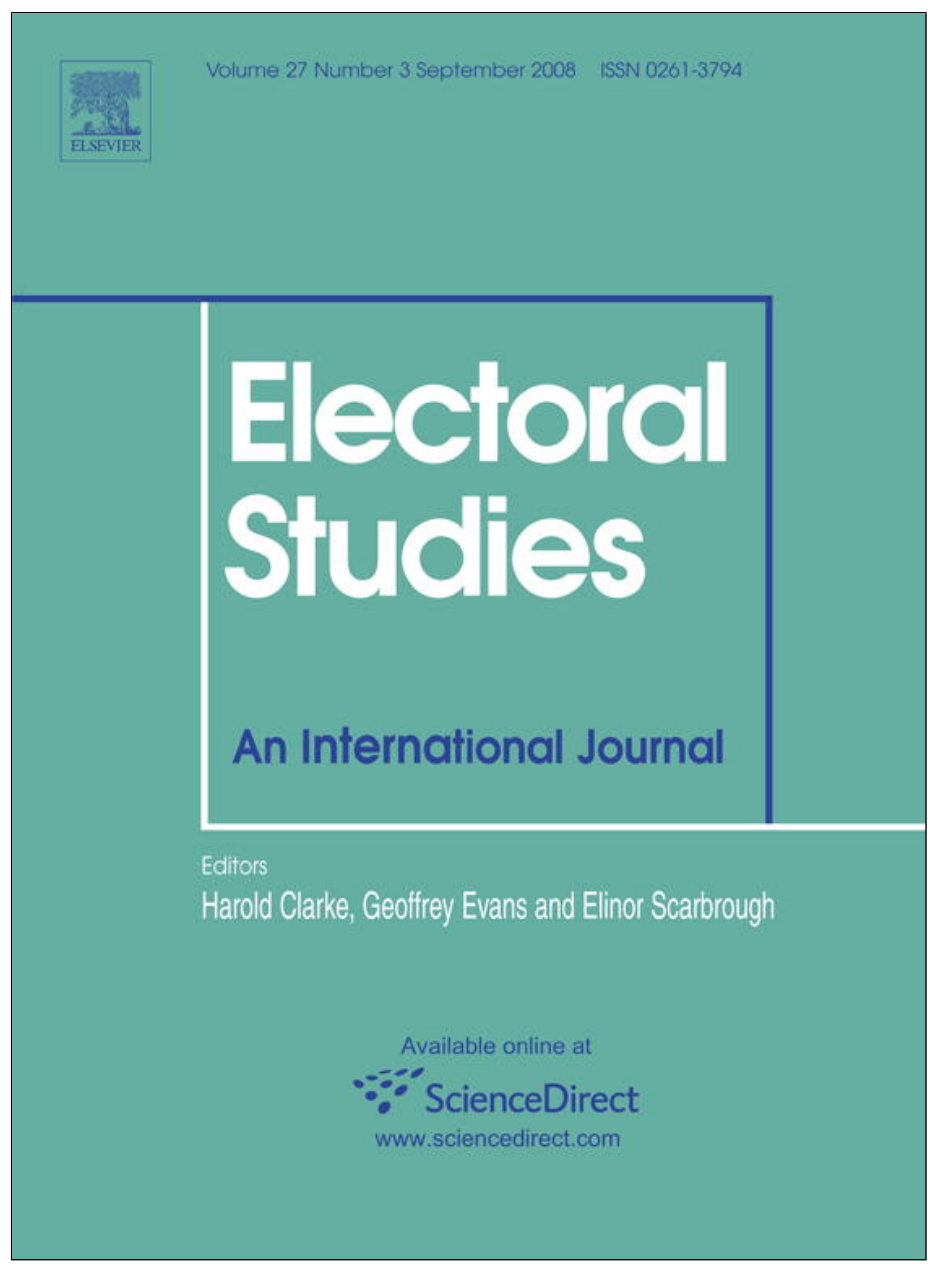

This article appeared in a journal published by Elsevier. The attached copy is furnished to the author for internal non-commercial research and education use, including for instruction at the authors institution and sharing with colleagues.

Other uses, including reproduction and distribution, or selling or licensing copies, or posting to personal, institutional or third party websites are prohibited.

In most cases authors are permitted to post their version of the article (e.g. in Word or Tex form) to their personal website or institutional repository. Authors requiring further information regarding Elsevier's archiving and manuscript policies are encouraged to visit:

http://www.elsevier.com/copyright 


\title{
Owning the issue agenda: Party strategies and vote choices in British elections
}

\author{
Jane Green $^{\mathrm{a}, *}$, Sara B. Hobolt ${ }^{\mathrm{b}}$ \\ ${ }^{a}$ School of Social Sciences, University of Manchester, Oxford Road, \\ Manchester M13 9PL, UK \\ ${ }^{\mathrm{b}}$ Department of Politics and International Relations, University of Oxford, Manor Road, \\ Oxford OX1 3UQ, UK
}

Received 14 June 2007; revised 19 December 2007; accepted 4 February 2008

\begin{abstract}
Explanations of party competition and vote choice are commonly based on the Downsian view of politics: parties maximise votes by adopting positions on policy dimensions. However, recent research suggests that British voters choose parties based on evaluations of competence rather than on ideological position. This paper proposes a theoretical account which combines elements of the spatial model with the 'issue ownership' approach. Whereas the issue ownership theory has focused mainly on party competition, this paper examines the validity of the model from the perspective of both parties and voters, by testing its application to recent British general elections. Our findings suggest that as parties have converged ideologically, competence considerations have become more important than ideological position in British elections.
\end{abstract}

(C) 2008 Elsevier Ltd. All rights reserved.

Keywords: Issue ownership; Valence; Voting behaviour; British elections; Party competition; Issue salience; Spatial models

\section{Introduction}

The classic spatial approach to party competition is based on the Downsian model: parties maximise votes by adopting a position on a policy dimension (Downs, 1957). On the basis of this theory we expect parties to gravitate towards the median voter in a two-party system, when preferences are normally distributed. The corresponding expectation is that voters

\footnotetext{
* Corresponding author. Tel.: +44 (0)161 275 4855; fax: +44 (0)161 2754925 .

E-mail addresses: jane.green@manchester.ac.uk (J. Green), sara. hobolt@politics.ox.ac.uk (S.B. Hobolt).
}

choose parties closest to their policy preferences. ${ }^{1}$ However, in Britain the link between voter ideological position and vote choice appears to be weakening (Sanders, 1999). Clarke et al., argue in favour of 'competence' or 'valence' accounts of voting in place of ideological proximity (Clarke et al., 2004). In this paper we argue that these findings at the voter level must also have significance for our understanding of party competition.

\footnotetext{
${ }^{1}$ An alternative spatial model of voting, the directional model, posits that voters choose on the basis of an optimal party direction and message intensity (Rabinowitz and Macdonald, 1989). See also Merrill and Grofman (1999) for a unified model of voting.
} 
An alternative view of party competition proposes that parties primarily compete by emphasising different policy issues during a campaign. There are various incarnations of this approach: the 'dominance principle' (Riker, 1986, 1993), the 'saliency theory' (Budge and Farlie, 1983; Budge, 1993) and the 'issue ownership theory' (Petrocik, 1996; Petrocik et al., 2003). Common to all is the argument that parties seek to shape campaign agendas by emphasising issues that promote their strengths and by avoiding issues that give the opposition an advantage. A party will benefit if an issue on which it is perceived competent is also salient to voters. This focus on issue competence and issue salience provides a useful theory of party competition, particularly in the context of recent British patterns of voting behaviour. If voters no longer choose on the basis of ideology, as appears to be the case in Britain, the issue ownership theory may provide a better explanation of party strategies and vote choices.

Although several studies explore the application of the issue ownership theory at the level of party behaviour, very little research has investigated whether the theory is consistent with voting behaviour-an essential link if we are to subscribe to the assumption that parties adopt strategies in order to maximise votes (Strøm, 1990). This paper contributes by developing and testing a model of voting behaviour and of party behaviour that is compatible with the expectations of the issue ownership and issue salience theories. The guiding question is, to what extent do these theories explain party strategies and vote choices in recent British elections? We also offer an explanation for why competence-based theories become more relevant as parties converge on ideological dimensions: voters who cannot determine which party is closer to them in policy terms, because parties offer similar policies, will more likely choose between parties on the basis of which can deliver. In this way the valence and positional theories can be viewed as complementary. Our empirical analysis provides support for a rise in the importance of valence evaluations in place of positional evaluations, and this finding runs counter to existing empirical work (see Clarke et al., 2004). Rather than focusing exclusively on party competition, the paper combines party theories with voting behaviour analysis to provide a more comprehensive understanding of both. The implication is that commonly cited spatial theories should be augmented by a far greater focus on competence evaluations if we are to account for the electoral choices and party strategies in modern British politics and beyond.
The paper proceeds as follows. Following a review of the issue ownership theory, the first part of the paper presents a utility model of voting behaviour that combines elements from the spatial model of voting and the issue ownership theory. We show that by extending the classic Downsian unidimensional model to a multidimensional setting this model of vote choice is consistent with the issue ownership theory. Furthermore, we link the expectations of this model to recent trends in party and voter ideological convergence on the leftright spectrum in Britain. Next, we review the relevance of the spatial and the issue ownership theories to the strategies of the three main British parties in the 2005 general election campaign. Thereafter, we test the relative importance of the issue ownership and issue position models to the vote, analysing British election studies from 1987 to 2005 . We find that competence has increased in place of ideology as a predictor of vote choices just as the major parties have converged over time. In support of the issue ownership theory we also find that competence evaluations of parties matter more to vote choices when an issue is salient to voters. Our findings demonstrate that the issue ownership theory provides a more useful model for understanding party competition and voting behaviour when Downs' predictions of party convergence are met.

\section{The issue ownership theory of party competition}

Aldrich and Griffin (2003: 240) note, the "strategies the candidates choose in an election campaign-what they emphasise and what they ignore-have important effects on vote choices and therefore on outcomes". But why do candidates or parties choose to emphasise certain issues and ignore others? Scholars focusing on agenda setting argue that parties shape voter choices by campaigning on certain issues. In the communications literature this strategy is referred to as 'priming' and pertains to influencing the weighting of considerations in a given decision (Iyengar and Kinder, 1987). Parties attempt to 'prime' voters to consider certain issues relevant to their electoral choice. Riker (1993) states that the purpose of campaign messages is not to engage the opposition in debate or dialogue but to increase the salience of issues over which the party is perceived to be credible. He labels this the Dominance/Dispersion principle. Budge and Farlie (1983) have developed a saliency theory of party competition, likewise arguing that most political parties engage in selective emphasis of issues on which they have a competence 
advantage rather than direct confrontation with another party's issues. ${ }^{2}$ This theory has been formalised by Simon who deduces that "as no themes can work to the advantage of both candidates, they will never allocate resources to the same theme" (Simon, 2002: 64). A similar issue ownership theory has been advanced by Petrocik (1996) who argues that parties compete by emphasising issues where they have a stable reputation for greater competence: parties 'own' certain issues. The common expectation of all of these arguments, therefore, is that during campaigns parties promote issues on which they hold a long-standing reputation for competence. Henceforth the issue salience, dominance principle and issue ownership theory are called the 'issue ownership theory' given their similarities.

Whilst the issue ownership model is not built on an explicit model of voting behaviour, it is based on the assumption that voters are more likely to support parties they perceive as better at handling a specific policy concern. A similar view can by found in Stokes' classic valence model of voting (Stokes, 1963), formulated as a critique of the Downsian model. Stokes differentiated between valence issues and position issues. ${ }^{3}$ Valence issues are "those that merely involve the linking of the parties with some condition that is positively or negatively valued by the electorate", whilst position issues are those on which a set of alternatives exist "over which a distribution of voter preferences is defined" (Stokes, 1963: 373). On valence issues parties can be differentiated on competence but not on ideological position. Stokes (1963: 373) claims, "the machinery of the spatial model will not work if the voters are simply reacting to the association of the parties with some goal or state or symbol that is positively or negatively valued". Therefore competence should matter more in elections that are primarily fought on valence issues, whilst the spatial model is expected to provide greater explanatory power in elections dominated by position issues. This means that where voters and parties agree, the issue ownership model should have particular traction in explaining both the vote maximising strategies adopted by parties and the choices of voters (Green, 2007).

\footnotetext{
${ }^{2}$ See also Klingemann et al., 1994; Budge et al., 2001; Van der Brug, 2004; Clarke et al., 2005a.

3 See also: Butler and Stokes (1969), Stokes (1985) and Stokes (1992). The term 'valence' has since been used as a proxy for leadership ratings allowing for leverage over electoral strategy (Groseclose, 2001; Schofield, 2004); for candidate trustworthiness and honesty (Enelow and Hinich, 1982), and for economic performance ratings (Whiteley, 1984).
}

It is important to note that valence issues are defined as those issues where both voters and parties agree on the same goals whereas position issues are those on which parties and voters take different points of view. ${ }^{4}$ We recognise that the distinction could be overly simplistic. So-called valence issues may pose some positional differences and valence or competence judgements will still be relevant to the evaluations of parties on so-called position issues. However, issues will differ in the extent to which voters judge parties by their different policy options and the degree to which they judge parties as able or less able to deliver on the same goal. Whether an issue is more valence than positional is an empirical question which can be evaluated by exploring the association of positional or competence comparisons with respect to party choice. As stated by Stokes (1963: 373), "The question of whether a given problem poses a position- or valence-issue is a matter to be settled empirically and not on a priori logical grounds".

The following section offers a model for how these concepts can be viewed as complementary, such that the issue ownership model can be incorporated explicitly into the Downsian framework. We then provide empirical evidence to illustrate the timely application of the issue ownership theory to British elections and vote choices in recent years.

\section{Modelling voting behaviour and party competition}

In the proximity model, a voter's utility on each dimension for party $p$ is a declining function of policy distance from voter to candidate (Downs, 1957; Davis et al., 1970; Enelow and Hinich, 1984):

$U_{i j p}=-\left(P_{j p}-P_{j i}\right)^{2}+C_{j p}$

where voter $i$ 's overall evaluation of party $p$ 's utility on dimension $j\left(U_{i j p}\right)$ depends upon the squared distance between a party's position $\left(P_{j p}\right)$ and the voter $i$ 's own preferred position or ideal point on this issue $\left(P_{j i}\right)$. Since the utility declines with distance, a negative sign defines this utility function. The model presented above also includes the term $C_{j p}$, which captures the competence of a party on a particular issue dimension. This is also the 'handling' notion at the heart of the issue ownership theory: "a reputation... which leads

\footnotetext{
${ }^{4}$ Enelow and Hinich (1982) also assume that on position issues voters have different ideal points but on valence issues voters have the same ideal point.
} 
voters to believe that one of the parties is more sincere and committed to doing something about [the issue]" (Petrocik, 1996: 826). Several authors have introduced non-policy considerations, such as issue competence and likelihood of delivery, into the spatial voter calculus, showing that these factors can give one party an advantage with important implications for party differentiation (Enelow and Hinich, 1984; Enelow and Munger, 1993; Heath et al., 2001). Introducing nonpolicy factors can thus be seen as a logical extension of the Downsian model (see Grofman, 2004).

According to the simple Downsian median voter theorem, parties will converge around the median voter in a unidimensional space. Consequently, rational parties eliminate distances between each other, and voters can no longer choose between them on spatial grounds. Therefore, when policy distances between parties are modest, we can expect vote choice to be largely determined on the basis of which party is best trusted to deliver on this particular issue dimension. By contrast, if Downs' (1957) expectations are confounded and if parties offer more distinct policy choices, then positional evaluation should be given greater weight in the vote calculation. Spatial theories predicting policy divergence, such as the directional theory of Rabinowitz and Macdonald (1989) and theories relying on the influence of partisan policy divergence (Adams, 2001; Adams et al., 2005), activist interests or relative valence differentials (Schofield, 2003; Schofield and Sened, 2005) provide causal accounts for party divergence.

Our model draws a link between different party positional strategies and their impacts on the vote calculation. It combines the policy proximity considerations of the classic spatial model of voting with the competence considerations in the valence model of voting, and shows that some issues could be more valence in nature, and others more positional. Whilst these two models of voting are often presented as competing (e.g. Clarke et al., 2004), they can equally be presented as a unified model, illustrated in Eq. 1, and the question of their conceptualisation of valence or position issues is then determined by the relative weight given to each term. We expect issue competence or valence considerations to be relatively more important to a voter's utility when parties take very similar positions on an issue, whereas we expect proximity to matter more when parties are polarised.

This is highly relevant to British political competition. As the Labour Party moderated its position under Tony Blair and shifted to the centre, the political parties in Britain converged on the left-right dimension. Bara (2006) and Bara and Budge (2001) demonstrate growing similarity between the two major parties on the economic left- right dimension using data from the Comparative Manifesto Project. ${ }^{5}$ In order to evaluate whether voters perceive parties to be close to each other, thus influencing the vote utility calculation, we can also analyse voter perceptions of party positions using British Election Study (BES) data. Furthermore, we can ascertain whether voters are also more consensual, as we might expect from trends in dealignment, party cueing, and wider economic consensus. We are concerned here with the two major British parties. In the post-war period only the Labour and Conservative parties have held national office and hence these two parties represent the real government alternatives, which can be evaluated on ownership or 'valence' grounds by voters. In contrast, the smaller parties such as the Liberal Democrats, do not have a record of delivery in office and voters are consequently less likely to rate their 'issue ownership' highly, as we will show in subsequent analyses.

Fig. 1 presents the distance between the mean perceived location of the Labour Party and Conservative Party on a left-right dimension and also the distance between the mean location of Labour party identifiers and Conservative party identifiers. The left-right score is comprised by taking an average of the four highly correlated questions forming the left-right dimension within the BES cross-section surveys and panel surveys between 1987 and $2005 .^{6}$

\footnotetext{
5 These data are based on measures of party issue emphases not their relative positions. However, similar trends towards party convergence among the Labour and Conservative parties are found using voter perceptions (Green, 2007) and also using a measure of agreement that the main parties are similar or different (Curtice, 2005).

${ }^{6}$ Between 1987 and 2001 left-right position is derived as the average score from four summed issue scales in the cross-sections in 1987 and the 1992 to 1997 and 1997 to 2001 panel studies: 'nationalisation-privatisation' $(1=$ 'Nationalise many more private companies' to $11=$ 'Sell off many more nationalised industries'), 'inflation-unemployment' $(1=$ 'Getting people back to work should be the government's top priority' to $11=$ 'Keeping prices down should be the government's top priority'), 'equalise incomes' $(1=$ 'Make much greater efforts to make people's incomes more equal' to $11=$ 'Be much less concerned about how equal people's incomes are'), and 'tax-spend' $(1=$ 'Government should cut taxes and spend much less on health and social services' to $11=$ 'Government should increase taxes a lot and spend much more on health and social services'). In 2005 left-right position is derived from the summed and averaged values of 'tax-spend' (above) and 'left-right' (In politics, some people sometimes talk of left and right. Using the scale from 0 to 10 where 10 means left and 0 means right, where would you place....? (recoded to 1-11 for comparability)) scales in the absence of the other issue questions in these two cross-sections. There is certainly sufficient variation in the left-right measure for this substitution to be valid and if anything, including it probably overstates the differences in comparison to the issue scales. Also, the 2005 measure shows validity in relation to comparable available coding in the 1997 and 2001 BES surveys and using only the 'tax-spend' scale (available in all surveys) produces the same trends.
} 




Fig. 1. Perceived distance between the Labour and Conservative Parties and self-placement distance between Labour and Conservative identifiers on the left-right dimension.

The mean party placement scores are derived from the whole weighted sample in each survey. The $1987 \mathrm{BES}$ survey is the first survey from which the election studies contain directly comparable measures.

On the left-right dimension of British politics the identifiers of the two main parties have diminished in distance from each other. Between 1987 and 2005 the difference between the Labour identifier mean and the Conservative identifier mean drops from 2.7 to 0.9 and these figures coincide with a decline in the standard deviation among the whole sample of respondents (from 2.1 to 1.4 ), suggesting that convergence is reflected in the wider electorate. More dramatic has been the decline in the perceived distance between the two major parties. By 2005 respondents placed the Conservatives and Labour just one point apart on average on an eleven-point scale, and the perceived distance between parties declined in a comparable fashion to the mean distance between party identifiers across the time points.

These trends suggest, according to our argument, that parties now face strong incentives to compete on competence or valence differentiation rather than on spatial differences. The following section explores this possibility in relation to the 2005 British general election campaign.

\section{Issue salience and ownership in the 2005 general election}

According to the issue ownership theory, we expect parties to campaign on issues on which they have a relative advantage. However, unlike the existing approach, we do not think that parties can completely ignore issues that are highly salient to voters before the campaign begins. Some issues are likely to be highly salient to voters before the campaign, and such issues are likely to influence vote choices regardless of whether a single party ignores them (Bélanger and Meguid, 2004). Hence, we do not expect perfect divergence in the issue emphases of party campaigns. To examine the predictions of the issue ownership theory in the context of the 2005 British election we can approximate each party's ownership or relative competence advantage on each issue, and the preelection salience of issues, to predict each party's issue emphasis in the campaign.

MORI conducted opinion polls over many years asking respondents to rate issues as salient and to evaluate the three main parties on each. MORI asks, "What is the most important issue facing the country today?" and for each question "I would like you to tell me which party (Conservative, Labour or Liberal Democrat) has the best policies on each problem". Pre-election MORI issue salience and best party ratings avoid the problem of endogeneity in the relationship between party strategies and issue salience and we use these data to estimate the rational strategies of the three main British parties in the 2005 campaign. Fig. 2 presents the salience of each issue as percentage frequencies in February 2005, prior to the campaign.

In 2005, health and education were the two most salient issues and other salient issues included race/ 


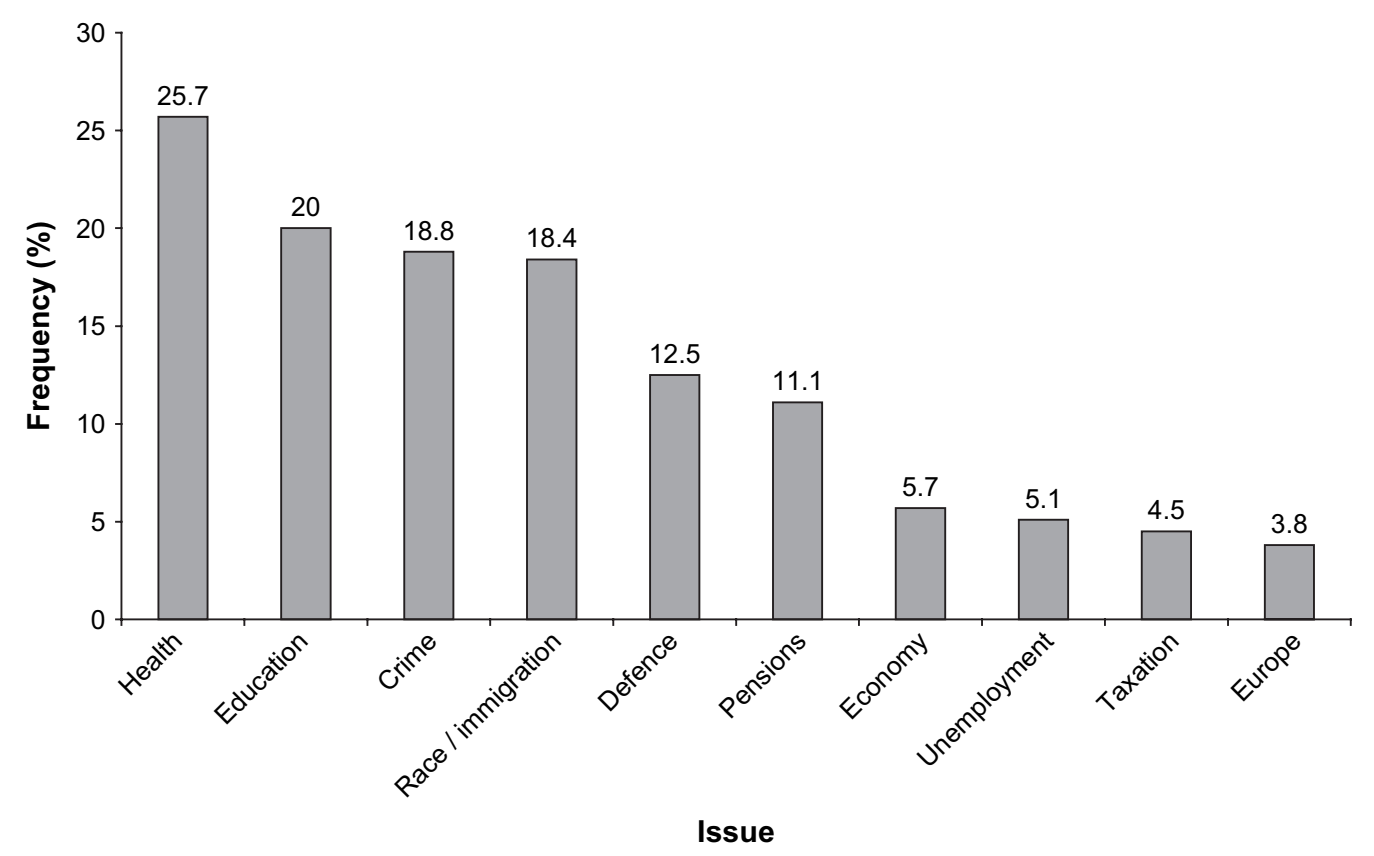

Fig. 2. MORI most important issues, February $2005(N=1074)$.

immigration and crime, and to a lesser extent defence and pensions. We would thus expect all parties to be more likely to campaign on these issues if parties respond to voters' most salient issues. However, contrary to a simple extension of the Downsian model, which would predict that parties respond to voter preferences in terms of policy position and the issues thought most important to voters, we expect parties to primarily prioritise issues where they also have a competence advantage.

Table 1 presents the relative advantage of each party in relation to the two other parties across the salient issues. Here we include the Liberal Democrats in the analysis in order to highlight the ownership of issues by the two major parties relative to the third party in British politics. The scores are calculated by simply subtracting one party's 'best party' percentage from the percentage for the party with which it is compared.

Labour has an advantage over the Conservatives on most issues and the party's largest relative advantage is on the economy. In addition to campaigning on the economy, we therefore expect that Labour will campaign on health and education to benefit from the salience of these issues. The economy is only rated the most important issue by 5.7 per cent of respondents. However, Labour's advantage is significant on this issue and the low salience rating may underestimate the wider significance

Table 1

MORI relative issue advantages, February $2005(N=1074)$

\begin{tabular}{|c|c|c|c|c|c|c|c|c|c|c|}
\hline & Health & Education & Economy & Defence & Pensions & Asylum & Taxation & Europe & Unemployment & Crime \\
\hline \multicolumn{11}{|c|}{ Labour advantage } \\
\hline Conservatives & 14.1 & 9.1 & 18.3 & 0.7 & 1.3 & -17.5 & -0.9 & 0.4 & 26.7 & -4.2 \\
\hline Lib Dems & 24.2 & 19.3 & 33.1 & 17.7 & 14.3 & 9.9 & 13.9 & 15.3 & 35.4 & 18.2 \\
\hline \multicolumn{11}{|c|}{ Conservative advantage } \\
\hline Labour & -14.1 & -9.1 & -18.3 & -0.7 & -1.3 & 17.5 & 0.9 & -0.4 & -26.7 & 4.2 \\
\hline Lib Dems & 10.1 & 10.2 & 14.8 & 17.0 & 13.0 & 27.4 & 14.8 & 15.3 & 8.7 & 22.4 \\
\hline \multicolumn{11}{|c|}{ Lib Dem advantage } \\
\hline Labour & -24.2 & -19.3 & -33.1 & -17.7 & -14.3 & -9.9 & -13.9 & -15.3 & -35.4 & -18.2 \\
\hline Conservatives & -10.1 & -10.2 & -14.8 & -17.0 & -13.0 & -27.4 & -14.8 & -15.3 & -8.7 & -22.4 \\
\hline
\end{tabular}

Note: All figures are percentage point differences between the 'best party' ratings of two parties on an issue. 
of the economy to the vote choice. ${ }^{7}$ Labour also owns the issue of unemployment but this issue was very low salience to voters in 2005. The Conservative Party appears to 'own' asylum/immigration, and it also has an advantage on crime. At 18.8 per cent crime is the third most important issue, only marginally less so than education (20 per cent), and immigration/race is a close fourth (18.4 per cent). The Conservatives can thus be expected to emphasise race/immigration and crime, which are both 'owned' and salient issues. Defence, Europe and taxation are net advantage issues in comparison with their ratings relative to the Liberal Democrats, but Europe and taxation in 2005 are the ninth and tenth lowest salient issues.

Neither the Conservatives nor Labour has an advantage relative to each other on defence. However, raising the salience of an issue will only increase the utility to a party on that issue if they are optimally located in proximity to public opinion. Given the controversy over the war in Iraq in the period leading up to the 2005 election, it is likely that defence was a positional issue according to the definitions used by Stokes (1963), summarised above. A majority of the population were against the Iraq war (according to the BES, 65 per cent of voters disapproved of the war in Iraq in 2005), but both Labour and the Conservatives were in favour, and hence, only the Liberal Democrats were located optimally (close to the median voter) to exploit this issue. Therefore whilst the Liberal Democrats do not have a relative issue ownership advantage of that issue, or any issue, since the party cannot realistically hold a handling advantage, the party has an incentive to emphasise the issue of Iraq in 2005 due to its positional advantage.

\section{Party strategies in the 2005 British election}

In order to evaluate our propositions in the context of the 2005 campaign, we need to obtain reliable measures of party issue emphases. Party policy programmes, particularly manifestos, are most commonly used (see Laver, 2001; Pennings, 2005). However, party manifestos are designed to give a broad overview of a party's policy platform and these documents are often the result of a long consultation process, aiming to satisfy internal interests (Bara, 2006). Parties use

\footnotetext{
${ }^{7}$ Economic voting theories have shown that voters who are feeling optimistic about the economy are more likely to vote for the incumbent government's return (Lewis-Beck and Stegmaier, 2000; Dorussen and Taylor, 2002). But see Evans (1999) and Evans and Andersen (2006) for the view that that the effects of economic perceptions on political support are greatly exaggerated, owing to the endogeneity of economic perceptions with respect to partisanship.
}

Table 2

Party issue priorities in the 2005 election campaign

\begin{tabular}{|c|c|c|c|c|}
\hline & Labour & Conservatives & $\begin{array}{l}\text { Liberal } \\
\text { Democrats }\end{array}$ & $\begin{array}{l}\text { Mean issue } \\
\text { emphases (S.D.) }\end{array}$ \\
\hline Health & 16 & 14 & 13 & $15(1)$ \\
\hline Education & 31 & 17 & 33 & $27(7)$ \\
\hline Crime & 9 & 25 & 5 & $13(9)$ \\
\hline Immigration & 5 & 14 & 1 & $6(6)$ \\
\hline Defence & 2 & 3 & 22 & $9(9)$ \\
\hline Pensions & 1 & 4 & 9 & $5(3)$ \\
\hline Economy & 28 & 6 & 5 & $13(11)$ \\
\hline Unemployment & 3 & 1 & 0 & $2(1)$ \\
\hline Taxation & 3 & 14 & 10 & $9(5)$ \\
\hline Europe & 1 & 1 & 1 & $1(0)$ \\
\hline
\end{tabular}

Source: party leader speeches, party election broadcasts and party press releases.

other means of communication to attract voters. We analyse three key forms of campaign communication: campaign speeches, party election broadcasts and press releases. ${ }^{8}$ Computer-aided content analysis of these documents is used to derive estimates of party issue emphases. This quantitative method is often used when large amounts of textual data are processed and interest lies primarily in manifest rather than latent content (for example, see Laver, 2001). Studies have shown that this technique is suitable for generating valid and reliable estimates of policy positions (Krippendorff, 1980; Laver and Garry, 2000; Garry, 2001; Bara, 2001). The parties' issue priorities are obtained by calculating the relative frequency of all coded words and quasi-sentences, corresponding to ten policy categories in a 'dictionary' file.' These were the ten most mentioned questions in response to MORI open-ended salience questions. This analysis captures the relative weighting given to each category as a percentage of the overall frequency of policy terms. Table 2 provides a summary of the issue emphases of the three main parties in the 2005 election campaign.

We can see that Labour campaigned in 2005 on their owned issues: education, the economy and health. The Conservatives appear to exploit their issue advantages in a campaign that focuses on crime, immigration and taxation, in addition to the highly salient (but Labour owned) issues of education and health. The

\footnotetext{
${ }^{8}$ Appendix A gives further details on the content analysis methods as well as an overview of the length and number of documents used for this analysis. Our results are consistent with content analysis of the parties' local campaign leaflets in 2005 by Fisher et al. (2007).

${ }^{9}$ Computer-aided techniques may also have certain advantages with regard to validity, since the coding process is mechanical and thus unbiased by any prior knowledge or opinions of an expert coder (Laver and Garry, 2000).
} 
Table 3

Top 3 ranked issues across types of communication in the 2005 campaign

\begin{tabular}{llll}
\hline & Leader speeches & PEBs & Press releases \\
\hline Labour & Education, economy, immigration & Economy, education, health \\
Conservatives & Education, crime, immigration & Crime, education, immigration & Economy, education, health \\
Liberal Democrats & Education, Iraq, health & Education, Iraq, health & Crime, taxation, education \\
\hline
\end{tabular}

Source: party leader speeches, party election broadcasts (PEBs) and party press releases.

Note: issues owned by the party are in bold. Issues owned by no party are in italic.

Liberal Democrats chose the issue of Iraq (defence) as the second most prominent issue of their campaign where they had a positional advantage, after the highly salient issue of education.

We can also look at each of the three types of party communication separately. Table 3 shows the three top ranked (most mentioned) issues by the three parties in the leaders' speeches, the Party Election Broadcasts and press releases. Each party's owned issues are highlighted to make it easier to identify issues that are distinct to individual parties. Issues that are not clearly owned by any of the parties - with an issue advantage of less than 5 per cent-have been italicised.

Labour campaigned primarily on its owned issues across all forms of campaign information. Interestingly, Tony Blair also addressed the immigration issue more frequently than we would expect, given the Conservative lead on this issue (although only 11 per cent of Blair's speeches emphasised immigration compared with a 46 per cent emphasis on education). However, Labour's press releases and election broadcasts conform with our expectation that Labour campaigned on owned issues that are salient to the public. The Conservatives campaigned on the issue of immigration-an issue which had become highly salient to the public - in both speeches and election broadcasts. The messages of the Liberal Democrats were almost perfectly consistent across types of communication, emphasising the Iraq war in $2005 .^{10}$

On issues that are clearly 'position issues' (such as Iraq), parties with a positional advantage exploit these in the campaign, lending support to a more traditional

\footnotetext{
${ }^{10}$ We also analysed voter utilities and party issue emphases in the 2001 general election campaign. These results confirm the issue ownership theory. In 2001 Labour emphasised the economy, education and health, consistent with its ownership advantage and with the salience of those issues. The Conservatives had ownership of immigration but the issue was less salient (9.5 per cent). The party emphasised crime, education, taxation and Europe, consistent with voter utilities. It had a positional advantage on this last issue. The Liberal Democrats emphasised the most salient issues, as well as pensions. Earlier elections cannot be examined due to unavailability of data.
}

spatial view of party competition. We find support in 2005 for the expectation that parties tend to campaign on owned issues if they have them. However, the findings also suggest that whilst parties employ selective issue emphasis, they gravitate towards the issues that are highly salient to the public. Although parties make strategic attempts to influence campaign agendas, they also respond to public issue priorities. The findings show strong support for the relevance of the issue ownership theory of party competition in the British case, and also the importance of issue salience in the strategies of the three parties.

These campaign strategies are consistent with a votemaximising theory of party competition to the extent that issue competence ratings (issue ownership) have an important impact on vote choices and, to the extent that party ratings on issues impact vote choices the greater the salience of those issues. Parties are expected to base their strategies on expectations of how voters respond, and so it is important to be explicit about how voters react to party behaviour. This is explored in the next section.

\section{Voter expectations}

Following our theoretical model, we expect that the ideological (proximity) component of voter utility for a party has decreased in importance since 1987, as the distance between voters and party position $\left(P_{j p}-P_{j i}\right)$ for the two major parties has diminished. Conversely, our model predicts that issue competence or ownership have become more important to the vote calculation in 2005. These expectations can be expressed in the following hypotheses.

H1: When parties diverge ideologically, respondent ideological position will be more strongly associated with vote choice than when parties are ideologically convergent.

$\mathrm{H} 2$ : When parties converge ideologically, respondent perception of party competence will be more strongly associated with vote choice than when parties are ideologically divergent. 
We predict that proximity and issue ownership considerations both matter to vote choice, but the latter will be relatively more important when the major parties have converged.

Another implication of the issue ownership theory is that issue competence is likely to matter more to vote choice when the policy issue in question is highly salient to voters. This is why we expect parties to seek to raise the salience of 'owned' issues by emphasising them during campaigns. Therefore we consider the salience of issues in terms of voter issue salience before campaigns and the degree to which parties shape agendas through their campaign emphases.

To understand the behaviour of parties and voters we need to go beyond the one-dimensional model. The basic Downsian model locates parties along a single (left-right) dimension, but an obvious extension is to consider multiple dimensions of issue competition. For simplicity's sake, we can present a campaign with two issue dimensions $j$ (indexed by $j=1,2$ ). In this simple model, voter $i$ 's overall utility from electing a particular party $U_{i p}$ depends on the utility derived from each dimension $j$, weighted by the salience of that dimension to the voter. We depict salience as a weight $w_{j}$ on each dimension (bounded between 0 and 1 ):

$U_{i p}=w_{i 1} U_{i 1 p}+w_{i 2} U_{i 2 p}$

The overall utility of voting for a party thus depends on the salience of that issue to the individual voter $\left(w_{i j}\right)$ and the voter's utility on each dimension $U_{i j p}$, described in Eq. (1), depending on proximity and issue competence considerations.

Following the one-dimensional model (in Eq. (1)), the main strategy options for a party are either to change position closer to the median voter and/or improve reputation on that issue. Both strategies are difficult to implement in the short-run. Perceptions of issue position and issue credibility are built over long periods of time and radical changes in the former may harm the latter. However, parties can aim to manipulate salience more readily in campaigns (Budge, 1994; Budge et al., 2001). If we turn to the multidimensional model of voting behaviour (Eq. (2)), parties therefore have another strategy option available to them, namely to influence the salience of the issues on which they have an advantage. A party that enjoys high competence ratings on issue dimension 1 , but is perceived to be less competent on issue dimension 2, may seek to influence the salience associated with issue $1\left(w_{1}\right)$ by campaigning intensely on this issue, ignoring issue dimension 2. Our model also leads us to expect that a party with a positional advantage will seek to raise the salience of that issue. If this strategy is successful, the issue dimension will carry greater weight in a voter's subsequent judgment. A party must also respond to an issue that is already highly salient. This model can be formulated as an implication of the issue ownership theory of party competition:

H3: Voters rating a party more competent on an issue will be more likely to vote for that party if they also perceive the issue to be salient.

\section{Testing the voting behaviour assumptions}

This section examines the voter level claims made in the theoretical section of this paper. The first claim, specified in the first hypothesis, is that we should expect ideological position to be closely associated with vote choice in periods of party divergence and more weakly associated with vote choice in periods of party convergence. The second claim, set out in the second hypothesis, is that competence ratings of parties will be more strongly associated with vote choice when parties have converged ideologically. The first two relationships are explored in concert by comparing the effect of ideology and competence on vote choice in the five general elections from 1987 to 2005. This period provides an apposite test for our theory since it captures the movement of the two major parties from a position of high polarisation to ideological convergence (see Fig. 1). The election studies in these years also provide the only consistently available measures of voter-party positions as well as measures of competence that are not simply leader evaluations, used elsewhere (Clarke et al., 2004). We explicitly test the theory for choices between the two major parties, given these parties' movements and the ability of voters to differentiate between potential and previous parties of government on the basis of competence and delivery. The previous analysis of the 2005 general election showed that the Liberal Democrats have no issues over which they realistically have a competence, ownership or valence advantage. If the issue ownership model is to provide traction in explaining party competition, we need to evaluate the degree to which the model is consistent with the specific interaction between issue ownership and issue salience. Hence lastly we estimate models to explore the relationship of issue competence ratings and issue salience to vote choice, in order to test our third hypothesis. 


\subsection{The effect of issue position and issue ownership,} 1987-2005

We expect that the ideological proximity between parties has become less important over the last three elections, as the parties have converged ideologically, compared with earlier elections. Equally, we expect that voters' perceptions of party competence have become more strongly associated with vote choice in these recent elections. To test these expectations we examine the marginal effect of ideological proximity and perceptions of competence on vote choice for the incumbent party against the main opposition party in each election from 1987 to 2005 .

Ideological proximity is measured as the distance between the voter's position and the incumbent party position on the composite left-right scale used earlier. We use the 1987, 1992, 1997, 2001 and 2005 BES cross-sections (rather than panel studies, as above) to measure the relationship to vote choice rather than vote intention. In 1987, 1992 and 1997 the scale is the composite left-right measure based on four policy questions and in 2001 and 2005 it is the tax-spend and 'left-right' label measure. Unfortunately the surveys do not enable us to use exactly the same measure in all years, and hence to evaluate the robustness of the composite left-right scale we have also estimated models with only the 'tax-spend' question. We find the same results. The measures are calculated by subtracting respondent position from the mean location of the Labour or Conservative party as perceived by voters in each case, ${ }^{11}$ and thus measures the ideological 'proximity' (or distance) component of the model.

There is no direct measure of perceived party competence consistent across election studies, so we use the question of whether the party is 'capable of strong government ${ }^{12}$ as the best available proxy of the government's competence and 'handling ability'. This is the only consistent measure included in the surveys over time and we believe it is substantively preferable to using leader ratings (as used by Clarke et al., 2004) as a proxy for competence. The ability to handle issues tends to be correlated with the ability of strong government, whereas leader ratings encompass a wider range of personal evaluations beyond evaluations of valence.

\footnotetext{
$\overline{11}$ We also estimated models with the distance between voter position and individual (rather than mean) perceptions of the position of the party. The results were consistent.

12 The variable is coded $1=$ capable, $2=$ don't know/neither, and $3=$ not capable.
}

Appendix $\mathrm{C}$ shows an overview of available competence measures in the British Election Studies. As shown, other than leader measures, which are not direct measures of competence, the 'capable of strong government' question is the only available proxy for competence, until 2005 when a more sophisticated analysis is made possible (see below).

The dependent variable is vote choice coded $1=$ incumbent party and $0=$ main opposition party, so that in 1987 and 1992 the variable is $1=$ Conservative and $0=$ Labour, and from 1997 to 2005 the coding is reversed. ${ }^{13}$ We exclude abstainers since we are primarily interested in actual vote choices. ${ }^{14}$ Each model also controls for age, gender, social class (coded $1=$ routine non-manual, $2=$ petty bourgeoisie, $3=$ foremen and technicians, $4=$ working class, and reference group $5=$ salariat), party identification (coded $1=$ Labour, $2=$ Conservative, $3=$ Liberal Democrat, and the reference group $4=$ don't know and other) and ratings of the party leaders. ${ }^{15}$ We control for party identification and for evaluations of party leaders to isolate the effect of voters' evaluations of party competence on vote choice. We consider these controls to place strict demands on the statistical effects of our independent variables, given the variance traditionally explained by party identification and leader support. The control variables are taken from the pre-election survey of the 2005 BES and the independent variables from the post-election surveys.

Rather than presenting a series of five logistic regression models, we present the marginal effects of ideological proximity and perceptions of competence on the probability of voting for the incumbent government in each election, holding all other variables to their mean. In order to make these measures

\footnotetext{
13 Although we model choice of incumbent party in each case, the results are comparable for either Labour or Conservative vote choice in each case due to the binary coding of the dependent variable.

14 The relationship between party proximity, abstention and the competence or ideological bases of vote choices would, of course, be an interesting avenue for further research.

15 The leader questions have slightly varied across surveys, and so the 1987, 1992 and 1997 variables were taken from whether the leader is capable of being strong: "is [e.g. Neil Kinnock] capable of being strong?", where $1=$ not capable, $2=$ neither/don't know and $3=$ capable. In 2001 the question was "is [e.g. Tony Blair'] a strong leader?", coded $1=$ not strong, $2=$ neither/don't know and $3=$ strong, and in 2005 whether the leaders were considered to be competent, an interval scale from $0=$ not at all competent to $10=$ very competent, recoded to the same three levels as before, so that $1=$ not competent (values 0 to 3 ), $2=$ neither competent or not competent (values $4-6$ ) and $3=$ competent (values 7-10).
} 


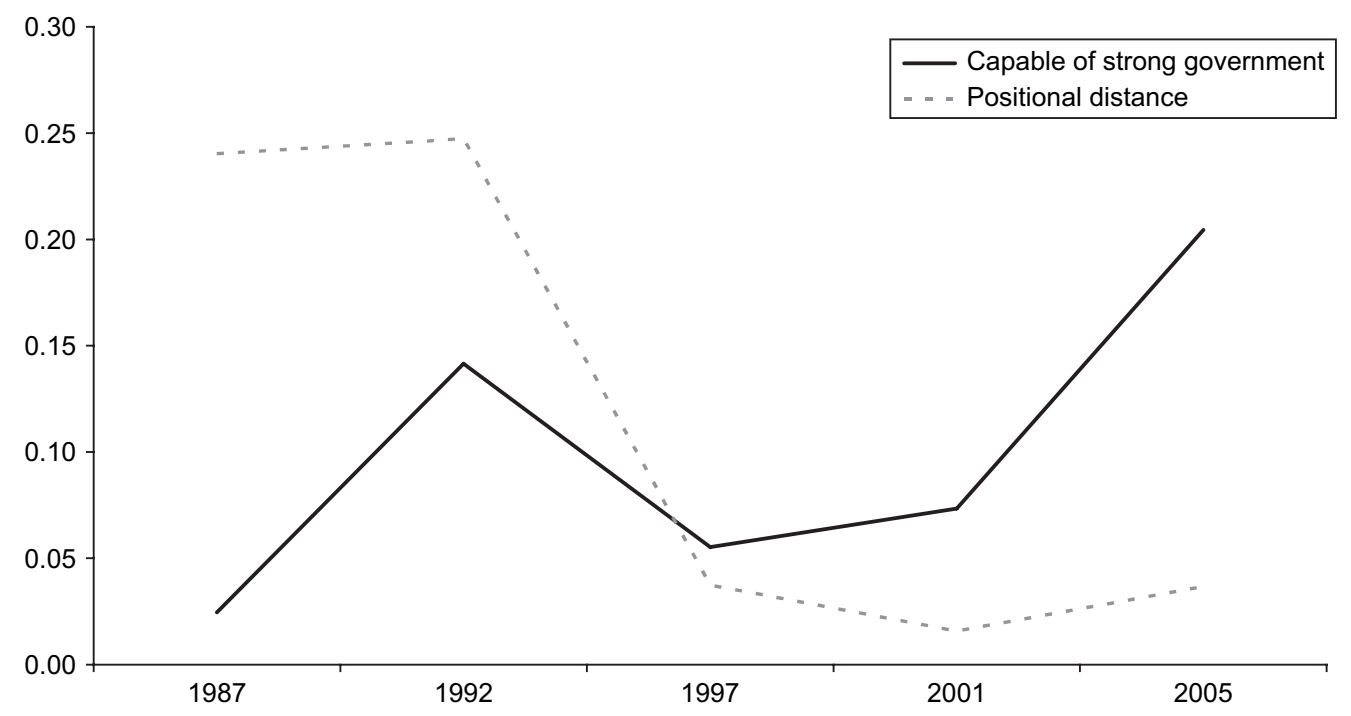

Fig. 3. Changes in marginal effect of left-right distance and strong government scores upon incumbent vote choice. Source: BES cross-sections, BES (1987) $(N=2141)$, BES (1992) $(N=1051)$, BES $(1997)(N=1934)$, BES $(2001)(N=1406)$, BES $(2005)(N=1000)$.

comparable across surveys, we measure the marginal effect (the first difference) by increasing the proximity and competence measures one standard deviation from the mean and calculating the change in the probability of voting for the incumbent in separate models. These marginal effects are shown in Fig. 3.

The first differences displayed in Fig. 3 demonstrate a very substantial change in the impact of ideology and competence on vote choices across the five elections. It is not possible to reach firm conclusions about a trend on the basis of so few time points, but the marginal effect of a standard deviation change in the ideological proximity between voters and parties declines drastically from 24 per cent points in 1987 to only 4 per cent points in 2005 (when the effect of proximity is statistically insignificant). Conversely, the marginal effect of perceptions of the ability of strong government increased from 3 to 21 per cent. The confidence intervals (presented in Appendix B) demonstrate that the marginal effect of ideological proximity to the incumbent party was significantly different between the 1997-2005 values and the 1987-1992 values. Likewise the marginal effect of ratings of the incumbent as 'capable of strong government' was significantly different between 2005 and 1987, 1997 and 2001, although not with 1992.

These findings are in the direction predicted by our hypotheses and they are in contrast to earlier work. Clarke et al. (2004), using leadership as a proxy for 'valence', show a consistently strong leader effect over time. Here we show that controlling for leader evaluations, underlying competence ratings, insofar as we can measure them, appear to show an upward trend, consistent with our theory. This suggests that the basis of vote choices and party competition may have shifted from proximity explanations to valence explanations - a finding of substantive relevance to wider theory and to interpretations of individual elections. Furthermore, using a composite measure of left-right values, we show that ideology did not significantly decline in importance to vote choice prior to 1997, whereas using nationalisation-privatisation scores, and 'pro-big business and anti trade' scores, Sanders (1999) found an earlier declining effect. Whereas the issue of nationalisation has diminished in contention prior to 1997 (Heath et al., 2001), our measure represents continued variation and politicisation. Taxation and public spending have been salient issues in recent British elections. Using our composite scale, which should be a stricter test of the diminishing effect of left-right, we find a significant decline only after 1997. In combination with Fig. 1 above, we can see that between 1987 and 2005 there is a decline in the distance between Labour and Conservative party identifiers, the perceived distance between the Labour and Conservative Party, and therefore also the relationship between ideological position and the vote choice in each election. This appears to coincide with an increase in the association between competence measures and vote choice.

However, these developments are not entirely linear and some anomalies are present. The 1992 election 
Table 4

Predicted probability of voting Labour across health competence ratings and tax-spend issue position

\begin{tabular}{llll}
\hline Health handling scores & $\begin{array}{l}\text { Predicted probabilities } \\
\text { (95\% confidence intervals) }\end{array}$ & $\begin{array}{l}\text { Left-right position } \\
\text { (tax-spend scale) }\end{array}$ & $\begin{array}{l}\text { Predicted probabilities } \\
\text { (95\% confidence intervals) }\end{array}$ \\
\hline 1 (very badly) & $0.09(0.07-0.11)$ & 1 (right, 0-2) & $0.14(0.10-0.18)$ \\
2 (fairly badly) & $0.14(0.12-0.16)$ & 2 (right, 3-4) & $0.16(0.13-0.20)$ \\
3 (neither) & $0.22(0.20-0.24)$ & 3 (centre, 5) & $0.19(0.17-0.22)$ \\
4 (fairly well) & $0.33(0.29-0.36)$ & 4 (left, 6 -7) & $0.23(0.20-0.25)$ \\
5 (very well) & $0.45(0.39-0.52)$ & 5 (left, 8-10) & $0.26(0.23-0.30)$ \\
\hline
\end{tabular}

Source: 2005 British Election Study $(N=2584)$.

appears to be an outlier, where the strength of the government was very important. Ideological proximity also had a significant impact in 1992, and this is not unexpected given the relative ideological divergence of parties at this point. Clearly a longer time series would be needed to verify a general trend over time. Nevertheless, the findings, in concert with the analysis of party strategies in 2005, suggest that valence theories of party strategy and of voting behaviour have particular relevance in elections where the major parties battle for the centre ground. It would also be interesting to compare these findings with more directly posed issue handling or 'best party' questions over time, but unfortunately these question items were not available for all studies. However, issue handling questions are available in the $2005 \mathrm{BES}$, and in the next section we re-analyse the results for the 2005 election, in light of our party analysis, using a more exact indicator of competence.

\subsection{Issue position and issue ownership in 2005}

We now model the probability of voting Labour across different levels of competence evaluations and left-right placements, controlling for age, gender, social class and party identification. The measure of competence used in this analysis is a question on Labour's ability to handle the health issue, 'how well does the Labour Party handle the issue of [health]?' coded from $1=$ handles very badly, to $5=$ handles very well. As shown in Fig. 2, the health issue was the most salient issue to voters prior to the campaign. The comparable measure of ideology is the respondents' locations on the tax-spend scale. We expect competence ratings on public services to be more closely associated with vote choice than left-right positions. The issue of health is therefore a key issue on which we can compare these two variables on the decision to vote for Labour in 2005. In the models the tax-spend scale is compressed into a five-point scale for comparability with the issue handling scale. ${ }^{16}$ In this analysis, for validation, the dependent variable is Labour vote $(1=$ voted Labour and $0=$ voted other party or abstained). To compare the effects of issue competence and ideological considerations, we calculate the predicted probability of voting Labour for respondents rating the party on health from 1 to 5 , and then for respondents positioned from the right to left (1 to 5) of the tax-spend scale. Higher values denote a larger effect of these evaluations on the decision to vote Labour, keeping all other variables at their mean.

Table 4 demonstrates that the higher the positive evaluation of Labour on its perceived ability to handle the issue of health, the greater the likelihood that this issue ownership favoured the party in the 2005 vote. ${ }^{17}$ Also, the more in favour of increasing taxation and spending on public services a respondent was on the tax-spend scale, the more likely it was that the respondent would vote Labour. The perceived issue ownership of Labour on the issue of health was a more important predictor of voting Labour than was ideological position, although issue position was marginally more important than issue ownership if the party was rated poorly on its ability to handle the health system. The results therefore corroborate our findings in Fig. 3, which show that issue ownership, using this measure of issue handling competence, is more closely related to the decision to vote Labour in 2005 than is ideological position on the left-right scale. Thus on this dimension on which voters converge, we find that issue

\footnotetext{
${ }^{16}$ Data are weighted, and the sample is comprised of respondents surveyed in the pre and post election waves. The results are comparable to a model of Labour versus Conservative vote choice and also if leader evaluations are entered into the model.

${ }^{17}$ When ratings of Tony Blair are included in the model the differences between the effects are as follows: The predicted probability of voting Labour in 2005 changes from $0.11(0.08-0.14)$ to 0.33 (0.27$0.39)$ across health handling scores and from $0.13(0.09-0.17)$ to $0.23(0.20-0.27)$ across self-placement on the tax-spend scale (from right to left). Controlling for leader ratings essentially controls for the same variable as competence and therefore we use the model without leader effects.
} 
ownership is a more important factor in the vote calculation than is issue position, consistent with our argument.

\subsection{Issue ownership and issue salience}

Finally, and central to the issue ownership model, is the claim that owned issues benefit parties the greater their salience. We should find that increasing the salience of an issue on which a party has a relative advantage is consistent with vote-maximising behaviour. To evaluate this claim, we can analyse the relative impact of issue handling scores upon vote choice by the salience of issues. The following analysis compares the association of handling scores according to salience on two issues, health and asylum, in two separate models of vote choice, first for Labour vote in 2005 on the two owned issues by Labour and the Conservatives respectively, the issue of health (Labour's best issue in that year), and then for Conservative vote in 2005 on the issue of asylum/immigration (the Conservative's best issue in that year). ${ }^{18}$

The independent main effects are the five-interval scale, 'how well does the [Labour/Conservative] party handle health/asylum?' from 0 (very badly) to 4 (very well) and a dummy variable coded $1=$ health salient (or asylum salient) and $0=$ other. $^{19}$ The interaction term is comprised of the competence score multiplied by the salience of the same issue in the post-election survey. Post-election variables are used since we are interested in how parties' campaigns result in an association of salience to party choice. We also report in the text the findings using pre-election salience effects and interaction terms. The pre-election controls are the same as in previous models. Table 5 presents the model for Labour vote (model 1) and for Conservative vote (model 2).

The first model (1) confirms the expectations. Labour benefited from its ratings on the issue of health the more positive its handling rating on that issue. If voters condemned Labour's handling of the health system they were less likely to vote Labour when they also judged health the most important issue. The significant interaction term coefficient also shows that

\footnotetext{
18 The 2005 BES does not include issue competence evaluations in relation to the Liberal Democrat Party.

19 The issue handling scale is recoded 0 to 4 so that the interactions are substantively meaningful. The measure of salience for asylum uses a combination of two categories, summing responses for asylum and for immigration as the most important issues.
}

Table 5

Logistic regression model of Labour and Conservative vote in 2005

\begin{tabular}{|c|c|c|}
\hline & $\begin{array}{l}\text { Model 1: } \\
\text { Labour vote }\end{array}$ & $\begin{array}{l}\text { Model 2: } \\
\text { Conservative vote }\end{array}$ \\
\hline & Coefficient (S.E.) & Coefficient (S.E.) \\
\hline Model constant & $-1.09^{* *}(0.26)$ & $-1.16^{* *}(0.32)$ \\
\hline \multicolumn{3}{|l|}{$\begin{array}{l}\text { Demographic controls } \\
\text { (pre-election) }\end{array}$} \\
\hline Age & $0.00(0.00)$ & $0.03^{* *}(0.00)$ \\
\hline Gender (female) & $0.43^{* *}(0.11)$ & $0.15(0.14)$ \\
\hline \multicolumn{3}{|l|}{ Social Class } \\
\hline Routine non-manual & $-0.34^{*}(0.15)$ & $0.11(0.18)$ \\
\hline Petty bourgeoisie & $-0.24(0.14)$ & $-0.55^{* *}(0.19)$ \\
\hline Foremen and technicians & $0.23(0.19)$ & $-0.86^{* *}(0.24)$ \\
\hline $\begin{array}{l}\text { Working class } \\
\text { Salariat }\end{array}$ & $-0.12(0.15)$ & $-1.21^{* *}(0.24)$ \\
\hline \multicolumn{3}{|l|}{ Party identification } \\
\hline Labour & $1.81^{* *}(0.15)$ & $-1.74^{* *}(0.25)$ \\
\hline Conservative & $-1.17^{* *}(0.21)$ & $2.01^{* *}(0.18)$ \\
\hline $\begin{array}{l}\text { Liberal Democrat } \\
\text { None/don't know }\end{array}$ & $-0.51^{*}(0.21)$ & $-1.28^{* *}(0.29)$ \\
\hline Tax - spend self placement & $0.03(0.03)$ & $-0.11^{* *}(0.03)$ \\
\hline \multicolumn{3}{|l|}{ Post-election variables } \\
\hline $\begin{array}{l}\text { Labour handling } \\
\text { of health/Conservative } \\
\text { handling of immigration }\end{array}$ & $-0.50^{* *}(0.06)$ & $-0.57^{* *}(0.08)$ \\
\hline $\begin{array}{l}\text { Salience of health/ } \\
\text { immigration }\end{array}$ & $-0.53(0.34)$ & $0.50(0.29)$ \\
\hline Handling $\times$ salience & $-0.34^{*}(0.16)$ & $-0.38^{*}(0.19)$ \\
\hline$N$ & 2694 & 2555 \\
\hline Log likelihood & -1130.12 & -757.87 \\
\hline Pseudo $R^{2}$ & 0.31 & 0.47 \\
\hline
\end{tabular}

when respondents rated the issue salient and they rated Labour competent on the issue, the likelihood of voting Labour was significantly greater, even controlling for party identification. This suggests that Labour faced an electoral incentive to raise the salience of its best issue in 2005, and this corroborates the underlying vote maximising logic of the issue ownership theory. Parties have an incentive to raise the salience of the issues on which they are rated most competent. The results are the same if we use pre-election measures of health, avoiding the potential concern that the results reflect endogenous ratings of issue importance.

Model 2 examines the role played by the issue of asylum/immigration in Conservative vote choice in 2005. It demonstrates that the interaction between ratings of the Conservative Party on the handling of asylum/immigration and the salience of the issue is also significant, as we expect. Competence ratings 
have an important effect on vote choice, and this effect is greater for respondents who rated asylum/immigration salient. Using pre-election measures of asylum showed non-significant results for the salience of asylum and the interaction term. However, in the pre-election wave the asylum coding was only based on that one issue, asylum, whereas in 2005 we use a composite measure of asylum and immigration. These findings may reflect the composition of the measures. Our model controls for party identification, and so we believe that any potential endogenous effects are controlled for, but we cannot also rule out the possibility that Conservative voters took their issue concerns from their party choice, rather than visa versa. However, this dynamic would remain consistent with the rationale of the issue ownership theory.

In line with the theory advanced in the issue ownership literature, these findings show that evaluations of competence matter more to voters when an issue is salient to them. This evidence also supports the claim in Eq. 2, that influencing the weighting of owned issues increases the utility to a party in terms of vote-maximisation.

This section has tested the three core assumptions of the theoretical model. It supports the claims that the proximity component $\left(P_{j p}-P_{j i}\right)$ of the utility calculus is less important than competence (issue ownership) concerns to vote decisions (on traditional left-right issues) in situations where parties have converged ideologically. We have also shown that owned issues favour parties more when they are salient. This analysis therefore underlines the utility of the issue ownership model as a framework for understanding party competition and voting behaviour, in concert with our party level analysis showing that an issue ownership explanation of party election strategies is strongly consistent with an analysis of the party issue emphases in the 2005 general election campaign.

\section{Conclusion}

Agendas foreshadow outcomes: the shape of an agenda influences the choices made from it. ${ }^{20}$

Agendas do not come about accidentally. In any campaign, there is a wide range of issues on which communication can occur. The campaign strategies of parties are well-researched and carefully executed attempts to influence the public agenda in order to shape election outcomes. In this paper we have sought to explain why parties choose to emphasise particular policy

\footnotetext{
$\overline{{ }^{20} \text { Riker (1993): } 1 .}$
}

issues during election campaigns and de-emphasise others, and how this corresponds with the way in which voters decide. We argue that the issue ownership theory of party competition provides a better explanation of vote choice in recent elections than the Downsian model. Our theoretical model does not deny that spatial proximity models are important. Rather it argues that when the predictions of Downs (1957) are confirmed-when party locations converge upon the median voter-then complementary theories are warranted to explain the ways parties seek to win votes, and how voters choose parties. By combining proximity and issue ownership components, we argue that when there is a large degree of party polarisation on an issue dimension, questions of ideological positioning are likely to be more important than party competence and credibility. Conversely, when there is a large degree of party convergence, competence should matter more. Thus we attempt to provide a theoretical explanation for 'valence voting' and to account for the relationship between vote choices and the changing political context.

Our analysis of party competition in the 2005 British general election suggests that the issue ownership theory provides a particularly helpful tool for understanding party strategies in this election. Our findings also suggest that this theory is consistent with the choices of voters in the most recent British elections. We demonstrate that valence calculations on the consensual left-right dimension are consistent with perceived party convergence over time, and we then examine the relative impact of this diminished positional variable in relation to issue ownership evaluations. Not only do we find that competence evaluations are more important to the Labour vote than traditional issue position in the domestic domain since 1997, we also find that increasing the salience of such an issue brings a commensurate vote gain. A party competition model based on issue competence, position and salience is thus compatible with vote choices in this election, but a positional theory is more consistent with vote choice in 1987 and 1992-elections in which the major parties were perceived to be polarised in relation to each other.

These findings indicate that competence ratings have become more closely associated with vote choice. This may of course partly reflect the availability of our measures. We are not able to conduct a perfect causal test of our theoretical model and we are limited by the number elections in our analysis. However, by analysing a wide range of data on public attitudes as well as party behaviour, the results are based upon the most comprehensive time series of comparable questions available in British election 
studies. Our analysis of party strategies and perceived issue competence advantages point to the relevance of changes in valence and spatial evaluations for the two major parties. Future work may therefore test whether spatial vote models are more consistently important to third parties and other minor parties, as well as examining the interaction of changes in the vote bases to other electoral patterns, such as abstention. However, this paper not only tells a plausible and novel story about party competition over time, and specifically in the 2005 general election, but it also offers a theoretical framework for understanding party competition and voting behaviour that can be tested more rigorously in future research, both in cross-national and cross-temporal analyses.

\section{Acknowledgements}

We wish to thank Harold Clarke, Tim Hellwig, John Mehrtens, Laura Stoker and the anonymous reviewers of this paper for their valuable comments and suggestions.

\section{Appendix A}

Descriptive overview of party documents

\begin{tabular}{|c|c|c|}
\hline & \multicolumn{2}{|c|}{2005 campaign } \\
\hline & Words & No. \\
\hline \multicolumn{3}{|c|}{ Party election broadcasts } \\
\hline Labour & 3167 & 4 \\
\hline Conservatives & 2469 & 5 \\
\hline Liberal Democrats & 1881 & 4 \\
\hline \multicolumn{3}{|l|}{ Leader speeches } \\
\hline Labour & 22754 & 18 \\
\hline Conservatives & 31068 & 21 \\
\hline Liberal Democrats & 11492 & 13 \\
\hline \multicolumn{3}{|l|}{ Press releases } \\
\hline Labour & 54218 & 127 \\
\hline Conservatives & 37427 & 69 \\
\hline Liberal Democrats & 36975 & 124 \\
\hline
\end{tabular}

Note: The software program TEXTPACK 7.5 was used in our content analysis of these documents. To alleviate potential problems associated with context and homography, keywords in the dictionary have been identified using the keyword-in-context (KWIC) procedure, which highlights keywords within the context in which they are used. Ambiguous words were thereafter 'disambiguated' by using word strings and alternative signifiers to aid in contextualisation In addition to the 10 chosen policy categories, we also ran the analysis with additional policy areas (e.g. the environment, moral issues) to make sure that we have not overlooked important campaign issues, but none of these additional issues were given any significant emphases in the speeches.

\section{Appendix B}

Change in marginal effect of left-right distance and strong government scores upon incumbent vote choice including confidence intervals

\begin{tabular}{|c|c|c|}
\hline & Capable of strong government & Left-right distance \\
\hline & $\begin{array}{l}\text { Mean }+1 \sigma \\
(95 \% \text { confidence intervals) }\end{array}$ & $\begin{array}{l}\text { Mean }-1 \sigma \\
(95 \% \text { confidence intervals) }\end{array}$ \\
\hline 1987 & $0.025(-0.014-0.065)$ & $0.240(0.196-0.285)$ \\
\hline 1992 & $0.149(0.051-0.235)$ & $0.247(0.151-0.338)$ \\
\hline 1997 & $0.055(0.014-0.107)$ & $0.037(0.015-0.063)$ \\
\hline 2001 & $0.073(0.010-0.151)$ & $0.016(-0.065-0.093)$ \\
\hline 2005 & $0.205(0.140-0.267)$ & $0.037(-0.041-0.114)$ \\
\hline
\end{tabular}

Source: BES cross sections, BES (1987) $(N=2141)$, BES (1992) $(N=1051)$, BES $(1997)(N=1934)$, BES $(2001)(N=1406)$, BES (2005) $(\mathrm{N}=1000)$.

\section{Appendix C}

Competence measures in the British election studies

\begin{tabular}{|c|c|c|c|c|}
\hline Year & & Question & Party & Scale \\
\hline 1987 & Capable of strong government & V19d1 & Cons & 1 to 3 \\
\hline 1987 & Capable of strong government & V19d2 & Lab & 1 to 3 \\
\hline 1987 & $\begin{array}{l}\text { Leader good } \\
\text { at getting things done }\end{array}$ & v20a1 & Cons & 1 to 3 \\
\hline 1987 & $\begin{array}{l}\text { Leader good } \\
\text { at getting things done }\end{array}$ & v20a2 & $\mathrm{Lab}$ & 1 to 3 \\
\hline 1987 & Leader capable of being strong & $\mathrm{v} 20 \mathrm{~d} 1$ & Cons & 1 to 3 \\
\hline 1987 & Leader capable of being strong & $\mathrm{v} 20 \mathrm{~d} 2$ & Lab & 1 to 3 \\
\hline 1992 & Capable of strong government & v19a & Cons & 1 to 3 \\
\hline 1992 & Capable of strong government & $\mathrm{v} 19 \mathrm{~b}$ & Lab & 1 to 3 \\
\hline 1992 & Leader capable of being strong & $\mathrm{v} 24 \mathrm{a}$ & Cons & 1 to 3 \\
\hline 1992 & Leader capable of being strong & $\mathrm{v} 24 \mathrm{~b}$ & Lab & 1 to 3 \\
\hline 1997 & Capable of strong government & constrgov & Cons & 1 to 3 \\
\hline 1997 & Capable of strong government & labstrgov & Lab & 1 to 3 \\
\hline 1997 & Do a good job as PM & majpm & Cons & 1 to 4 \\
\hline 1997 & Do a good job as PM & blrpm & Lab & 1 to 4 \\
\hline 1997 & Blair capable of being strong & blstrld & Lab & 1 to 3 \\
\hline 2001 & Capable of strong government & bq16a & $\mathrm{Lab}$ & 1 to 3 \\
\hline 2001 & Capable of strong government & bq16b & Cons & 1 to 3 \\
\hline 2001 & Strong leader & $\mathrm{bq} 18 \mathrm{a}$ & Lab & 1 to 3 \\
\hline 2001 & Strong leader & bq18b & Cons & 1 to 3 \\
\hline 2005 & Competent leader & $\mathrm{bq} 16 \mathrm{a}$ & Lab & 0 to 10 \\
\hline 2005 & Competent leader & $\mathrm{bq} 16 \mathrm{~b}$ & Cons & 0 to 10 \\
\hline 2005 & Capable of strong government & $\mathrm{cq} 7 \mathrm{~b}$ & Lab & 1 to 3 \\
\hline 2005 & Capable of strong government & cq7a & Cons & 1 to 3 \\
\hline 2005 & Government handle issues (10) & $a q 4 a-j$ & Lab & 1 to 5 \\
\hline 2005 & Opposition handle issues (10) & $\operatorname{ag} 5 \mathrm{a}-\mathrm{j}$ & Cons & 1 to 5 \\
\hline 2005 & Government handle issues (6) & $b q 3 a-f$ & Lab & 1 to 5 \\
\hline 2005 & Opposition handle issues (6) & $\mathrm{bq} 4 \mathrm{a}-\mathrm{f}$ & Cons & 1 to 5 \\
\hline
\end{tabular}




\section{References}

Adams, J., 2001. Party Competition and Responsible Party Government: A Theory of Spatial Competition Based upon Insights from Behavioral Voting Research. University of Michigan Press, Ann Arbor.

Adams, J., Merril, S., Grofman, B., 2005. A Unified Theory of Party Competition: A Cross-National Analysis Integrating Spatial and Behavioral Factors. Cambridge University Press, Cambridge New York.

Aldrich, J., Griffin, J.D., 2003. 'The presidency and the campaign: creating voter priorities in the 2000 election'. In: Nelson, M. (Ed.), The Presidency and the Political System. Congressional Quarterly Press, Washington DC, pp. 239-256.

Bara, J., 2001. Tracking estimates of public opinion and party policy intentions in Britain and the USA. In: Laver, M. (Ed.), Estimating the Policy Positions of Political Actors. Routledge, London.

Bara, J., 2006. The 2005 manifestos: a sense of déjà vu? Journal of Elections, Public Opinion, and Parties 16 (3), 265-281.

Bara, J., Budge, I., 2001. Party policy and ideology: still New Labour? Parliamentary Affairs 54, 590-606.

Bélanger, É., Meguid, B., 2004. Issue salience, issue ownership and issue based vote choice: Evidence from Canada. Paper presented at the Annual Political Science Association Meeting, Chicago, September 2004.

Budge, I., 1993. Issues, Dimensions, and agenda change in postwar democracies: long-term trends in party election programs and newspaper reports in twenty-three democracies. In: Riker, W.H. (Ed.), Agenda Formation. University of Michigan Press, Ann Arbor.

Budge, I., 1994. A new spatial theory of party competition: uncertainty, ideology and policy equilibria viewed comparatively and temporally. British Journal of Political Science 24 (4), 443-467.

Budge, I., Farlie, D., 1983. Explaining and Predicting Elections: Issue Effects and party Strategies in Twenty-Three Democracies. George Allen and Unwin, London.

Budge, I., Klingemann, H.-D., Volkens, A., Bara, J., Tannenbaum, E. (Eds.), 2001. Mapping Policy Preferences. Oxford University Press, Oxford.

Butler, D., Stokes, D., 1969. Political Change in Britain: Forces Shaping Electoral Choice. Macmillan, London.

Clarke, H., et al., 2003. British General Election Study, 2001 [computer file]. UK Data Archive (distributor), Colchester, Essex, SN: 4619.

Clarke, H., Sanders, D., Stewart, M., Whiteley, P., 2004. Political Choice in Britain. Oxford University Press, Oxford.

Clarke, H., Sanders, D., Stewart, M., Whiteley, P., 2005a. Taking the bloom off New Labours rose: party choice and voter turnout in Britain, 2005. Journal of Elections, Public Opinion and Parties 16 (1), 3-36.

Clarke, H., et al., 2005b. British General Election Study, 2005 [computer file]. http://www.essex.ac.uk/bes/2005/Survey\% 20with\%20Mailback.htm, Colchester, Essex.

Curtice, J., 2005. Turnout: electors stay home-again. Parliamentary Affairs 58 (4), 776-785.

Davis, O.A., Hinich, M.J., Ordeshook, P., 1970. An expository development of a mathematical model of the electoral process. American Political Science Review 64, 426-448.

Dorussen, H., Taylor, M., 2002. Economic Voting. In: Dorussen, H., Taylor, M. (Eds.), Routledge, New York.

Downs, A., 1957. An Economic Theory of Democracy. Harper Collins, New York.
Enelow, J.M., Hinich, M.J., 1982. Nonspatial candidate characteristics. Journal of Politics 44 (1), 115-130.

Enelow, J., Hinich, M.J., 1984. The Spatial Theory of Voting. Cambridge University Press, Cambridge.

Enelow, J.M., Munger, M.C., 1993. The elements of candidate reputation: the effect of record and credibility on optimal spatial location. Public Choice 77 (4), 757-772.

Evans, G., 1999. Economics and politics revisited: exploring the decline in Conservative support, 1992-1995. Political Studies 47, 139-151.

Evans, G., Andersen, R., 2006. The political conditioning of economic perceptions. Journal of Politics 68 (1), 194-207.

Fisher, J., Denver, D., Fieldhouse, E., Cutts, D., Russell, A., 2007. Constituency campaigning in 2005: ever more centralization? In: Wring, D., Green, J., Mortimore, R., Atkinson, S. (Eds.), Political Communications: The General Election Campaign of 2005. Palgrave Macmillan, Basingstoke.

Garry, J., 2001. The computer coding of political texts: results from Britain, Germany, Ireland and Norway. In: Laver, M. (Ed.), Estimating the Policy Positions of Political Actors. Routledge, London.

Green, J., 2007. When Voters and parties agree: valence issues and party competition. Forthcoming in Political Studies 55 (3), 629-655.

Grofman, B., 2004. Downs and two-party convergence. Annual Review of Political Science 7, 25-46.

Groseclose, T., 2001. A model of candidate location when one candidate has a valence advantage. American Journal of Political Science 45 (4), 862-886.

Heath, A., et al., 1989. British General Election Study, 1987 [computer file]. UK Data Archive [distributor], Colchester, Essex, SN: 2568.

Heath, A., et al., 1993. British General Election Study, 1992 [computer file]. UK Data Archive [distributor], Colchester, Essex, SN: 2981.

Heath, A., et al., 1999. British General Election Study, 1997 [computer file], second ed. UK Data Archive [distributor], Colchester, Essex, SN: 3887.

Heath, A.F., Jowell, R.M., Curtice, J.K., 2001. The Rise of New Labour: Party Policies and Voter Choices. Oxford University Press, Oxford.

Iyengar, S., Kinder, D.R., 1987. News that Matters: Television and American Public Opinion. University of Chicago Press, Chicago.

Klingemann, H.D., Hofferbert, R.I., Budge, I., 1994. Parties, Policies and Democracy. Westview Press, Boulder.

Krippendorff, K., 1980. Content Analysis: An Introduction to its Methodology. Sage Publications, Beverly Hills.

Laver, M. (Ed.), 2001. Estimating the Policy Positions of Political Actors. Routledge, London.

Laver, M., Garry, J., 2000. Estimating policy positions from political texts. American Journal of Political Science 44 (3), 619-634.

Lewis-Beck, M.S., Stegmaier, M., 2000. Economic determinants of electoral outcomes. Annual Review of Political Science 3 (1), $183-219$.

Merrill, S., Grofman, B., 1999. A unified theory of voting: directional and proximity spatial models. Cambridge University Press, Cambridge.

Pennings, P., 2005. Parties, voters and policy priorities in the Netherlands, 1971-2002. Party Politics 11 (1), 29-45.

Petrocik, J.R., 1996. Issue ownership in presidential elections. American Journal of Science Review 58 (4), 825-850.

Petrocik, J.R., Benoit, W.L., Hansen, G.J., 2003. Issue ownership and presidential campaigning, 1952-2000. Political Science Quarterly $118,599-626$. 
Rabinowitz, G., Macdonald, S.E., 1989. A directional theory of issue voting. The American Political Science Review 83 (1), 93-121.

Riker, W.H., 1986. The Art of Political Manipulation. Yale University Press, New Haven and London.

Riker, W.H., 1993. Rhetorical interaction in the ratification campaigns. In: Riker, W.H. (Ed.), Agenda Formation. University of Michigan Press, Ann Arbor.

Sanders, D., 1999. The impact of left-right ideology. In: Evans, G., Norris, P. (Eds.), Critical Elections: British Parties and Voters in Long-Term Perspective. Sage Publications, London.

Schofield, N., 2003. Valence competition in the spatial stochastic model. Journal of Theoretical Politics 15 (4), 371-383.

Schofield, N., 2004. Equilibrium in the spatial valence model of politics. Journal of Theoretical Politics 16 (4), 447-481.

Schofield, N., Sened, I., 2005. Modeling the interaction of parties, activists and voters: why is the political center so empty? European Journal of Political Research 44, 355-390.
Simon, A.F., 2002. The Winning Message-Candidate Behaviour Campaign Discourse and Democracy. Cambridge University Press, Cambridge.

Stokes, D., 1963. Spatial models of party competition. American Political Science Review 57, 368-377.

Stokes, D.E., 1985. The paradox of campaign appeals and election mandates. Proceedings of the American Philosophical Society 129 (1), 20-25.

Stokes, D., 1992. Valence politics. In: Kavanagh, D. (Ed.), Electoral Politics. Clarendon Press, Oxford.

Strøm, K., 1990. A behavioural theory of political parties. American Journal of Political Science 34 (2), 565-598.

Van der Brug, W., 2004. Issue ownership and party choice. Electoral Studies 23 (2), 209-233.

Whiteley, P., 1984. Perceptions of economic performance and voting behaviour in the 1983 general election in Britain. Political Behaviour 6 (4), 395-410. 